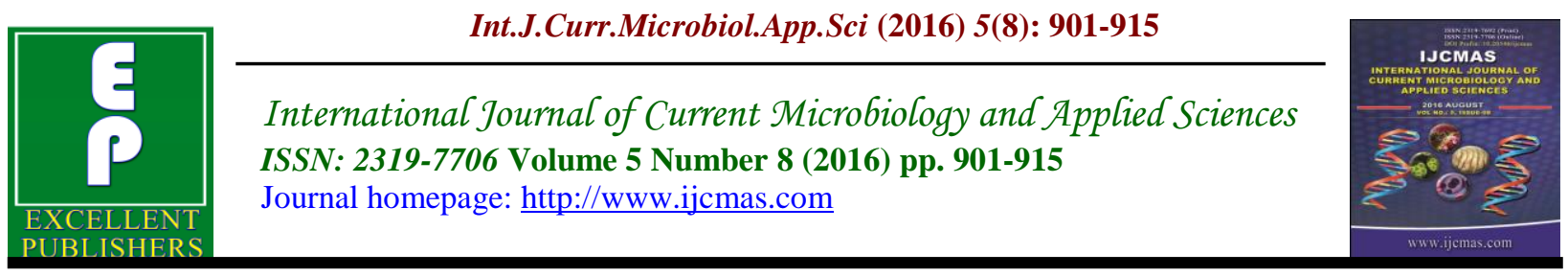

Original Research Article

http://dx.doi.org/10.20546/ijcmas.2016.508.102

\title{
Soil Amendment for Vegetable Production: An Example with Cow Dung Manure and Eggplant (Solanum melongena)
}

\author{
T.P. Abegunrin ${ }^{1}$, G.O. Awe ${ }^{2 *}$ and K.O. Ateniola ${ }^{1}$ \\ ${ }^{1}$ Department of Agricultural Engineering, LadokeAkintola University of \\ Technology, Ogbomoso, Nigeria \\ ${ }^{2}$ Department of Crop, Soil and Environmental Sciences, Ekiti State University, \\ PMB 5363, Ado-Ekiti, Nigeria \\ *Corresponding author
}

\section{Keywords}

Soil amelioration, farmyard manure, soil properties, crop performance

\section{Article Info}

Accepted:

20 July 2016

Available Online:

10 August 2016

\section{A B S T R A C T}

Soil degradation as a result of improper land use and management practices has limited the ability of the soil to produce optimally. Therefore, this study was aimed atassessing the effects of cow dung manure amendment on some properties of a degraded soil located within the Teaching and Research Farm, Ladoke Akintola University of Technology, Ogbomoso, Nigeria and the influence on the growth of egg plant (Solanum melongena). Soil samples were collected from 0-30 cm layer of the soil and were packed in pots. The soil samples in the pots were treated with 0 , 10, 15 and 20 ton/ha of cow dung designated as control, T1, T2 and T3, respectively in 3 replications. At harvest, soil samples were collected at $0-10$ and $10-20 \mathrm{~cm}$ depth in the pots for the analysis of physico-chemical properties. Plant growth parameters were monitored from five weeks after transplanting till harvest. The results revealed that at both depths $(0-10$ and $10-20 \mathrm{~cm})$, there was significant $(\mathrm{p}<0.05)$ decrease in soil bulk density (BD), and corresponding increase in total porosity $(\mathrm{Pt})$ and mean weight diameter (MWD). Soil $\mathrm{pH}, \mathrm{OC}, \mathrm{TN}$ and $\mathrm{P}$ significantly $(\mathrm{p}<0.05)$ increased while the $\mathrm{C}: \mathrm{N}$ ratio was decreased with application of cow dung. Plant height and number of leaves were significantly $(p<0.05)$ higher in soils amended with cow dung, with treatment T3 (20 ton/ha) giving the best results. The results showed that cow dung has great potentials for amelioration of degraded soils however further studies are required to establish optimum rate for sustainable crop production. Also the increase in $\mathrm{P}$ loading with increasing application rates also call for further investigation in terms of negative impact on the environment.

\section{Introduction}

Degraded soil results not only due to natural phenomena but also from improper land use and management practices over years causing decline in soil functions. For instance, the increasing pressure on soil resource to increase crop production to meet food demand of increasing world population has made the traditional shifting cultivation to be obsolete and the bush fallow system for maintaining the productivity, shorter. 
Thus soils are no longer naturally able to supply the needed nutrients required by plants with a consequent decline in yield (Amhakhian et al., 2010). Therefore, efforts are being made in almost every country of the world to reclaim degraded soils for agricultural purposes. Nevertheless Ahmad et al., (2014) stated that the success of fertility rehabilitation projects require recovery of soil organic matter and mineral nutrient cycling in the soil. In this context, the use of organic materials or organic agriculture as soil amendments has been accorded considerable attention for reclamation of degraded soils for nutrient recovery and recycling and increase crop productivity, using available resources and management such as green manure (Alves and Souza, 2008; Bonini and Alves, 2010), crop rotation (Ahmad et al., 2014), compost and bio solids (McGeehan, 2012; Abubakari et al., 2015), livestock waste (Ewulo, 2005; Ikeh et al., 2012; Oyewole et al., 2014), vermicompost (Moraditochaee et al., 2011), however results are site-specific depending on soil type, climatic condition and cultural practices.Despite the success of the various schemes, not much is known on the applicability and efficacy of cow dung for soil amendment.

Managing cow dung is a common problem as other animal wastes in developing countries such as Nigeria. Putting these wastes into effective agrarian use is also often a problem because they are bulky, low-grade in terms of nutrient contents. Cow dung has high water content, making it cumber some to transport far from the source to the point of use. In addition, the irritating malodorous gases emanating further complicate its use. Despite these shortcomings, cow dung has potentials to alleviate soil nutrient depletion problems in crop production (Ahmad et al., 2014). Fening et al., (2008) identified cow dung as soil amendment that possesses the potential for use in the interior savannah zone of Ghana. In Nigeria, few studies have explored the potentials of cow dung for soil amelioration and crop performance (e.g. Ewulo, 2005; Ewulo et al., 2007).

Eggplant (Solanum molengena) is one of the most important grown vegetable in West Africa, it originated from tropical Africa, and is well adapted to tropical climate (Tindall, 1992). The crop is known by many names such as eggplant and aubergine in the United States and Europe, brinjal in the South East Asia and garden egg in West Africa including Nigeria (Obeng-Ofori et al., 2007). Depending on the variety, the crop is grown for the fresh fruits (eaten raw or cooked) or the leaves. The fruits are known for being low in calories and rich source of potassium, magnesium, calcium and iron (Zenia and Halina, 2008). Because of the nutritional value beneficial for human health, the production of eggplant has recently increased, resulting into continuous use of same land every year and encroachment of marginal lands. According to Stoorvogel et al. (1993), continuous cropping with low or no soil amendment, nutrient losses through harvest, soil erosion and leaching cause decline in soil fertility. Just as other vegetables, eggplant also requires balanced soil nutrients for optimum yield. In this context, several studies have evaluated the effect of different soil amendments on growth and yield of eggplant (e.g. Dauda et al., 2005a, b; Moraditochaee et al., 2011; Suge et al., 2011; Oyewole et al., 2014), but none of these studies have reported the soil condition due to the various amendments. However, such information is vital for management decision towards sustainable environment.

Majority of the land used for eggplant (and other vegetable crops) production in 
Ogbomoso has been degraded due to continuous cropping and washing away of top soil due to the scouring velocity of irrigation water, with consequent sharp drop in yield and low income. Thus, there is the need for comprehensive approach towards rehabilitation of such farms. Therefore, the aim of this study was to assess the effects of soil amendment using cow dung manure on some physical and chemical properties of a degraded soil and the influence on the performance of egg plant (Solanum melongena).

\section{Materials and Methods}

\section{Description of the Study Area}

The study was conducted in the experimental field of Department of Agricultural Engineering, Ladoke Akintola University of Technology (LAUTECH), Ogbomoso (Latitude $8^{\circ} 10^{\prime} \mathrm{N}$ and longitude $4^{\circ} 10^{\prime}$ E). Ogbomoso is marked with a distinctive rainy season, averaged at eight months (April- October) with mean annual rainfall of over $1000 \mathrm{~mm}$ (Olaniyi et al., 2010). The rainfall distribution is bimodal with peaks in July and September, with a period of low precipitation in August (August break). The mean minimum and maximum temperature is 28 and $33^{\circ} \mathrm{C}$, respectively. Relative humidity is quite high- about 70\% (Ganiyu et al., 2013).

A degraded soil under eggplant cultivation was located within the campus of LAUTECH. Samples were collected at the depth of $0-10$ and $10-20 \mathrm{~cm}$ of the soil profile, the sample was tested for organic carbon (OC) and total nitrogen (TN). These were done to estimate the fertility level of the soil. The results of the test indicated that the soil is degraded. Afterwards, disturbed soil samples were collected at the depths 010 and $10-20 \mathrm{~cm}$ of the soil layer. The samples were taken to the laboratory for analyses. Other routine parameters analysed using standard laboratory procedures included Organic Carbon (OC) Total Nitrogen(TN), Total Phosphorus (P), pH, Electrical Conductivity (EC), Aggregate Stability (WSA), Bulk Density (BD), C:N ratio and Total Porosity $(\mathrm{Pt})$.

\section{Experimental design}

The experiment was laid out in randomized complete block design (RCBD) in three replications. The treatment consisted of four levels of cow dung namely: T1: 10ton/ha; T2: 15 ton/ha and T3: 20 ton/ha and control: 0 ton/ha.

\section{Preparation of mini-lysimeters}

The materials used for this work include plastic pots (made from $20 \mathrm{~L}$ buckets, $58 \mathrm{~cm}$ diameter and $33 \mathrm{~cm}$ high. The pots (twelve in numbers) were perforated at the bottom to allow for free drainage of water that could have contributed to deep percolation. A metallic measuring tape was used to measure (from the surface) the depth of soil and samples collected and done in the range of $0-10,10-20$ and $20-30 \mathrm{~cm}$. The inside of the pots were divided into three sections. About $5 \mathrm{~cm}$ depth from the tip of each pot was left to allow water to be collected from rain and to avoid runoff from the surface of the pot. Soil samples collected from each layer were used to fill each section, with soil from $20-30 \mathrm{~cm}$ at the bottom in that order. The pots were arranged on the field following the experimental design. Before transplanting, the pots were then left on the field for one week for possible rearrangement of the soil particles.

\section{Soil treatment and planting}

The soil in the pots previously arranged according to the experimental design were treated with three levels of cow dung (10, 15,20 t/ha). Cow dung, dried to $17 \%$ 
moisture content and ground into fine, soillike texture (Traunfeld and Nibali, 2013), was in corporate into the superficial layer of the pots and were left in the open field for two weeks before transplanting. Three week old seedlings of garden egg (Solanum melongena) which have earlier been raised in a nursery within the experimental field were transplanted at two plants per each pot. The pots were watered adequately to ensure crop establishment. There was no inorganic fertilizer application and weeding was done manually throughout the growing period of the vegetable.

\section{Soil sampling and analysis at harvest}

After harvest, both disturbed and undisturbed soil samples were carefully collected from the $0-10$ and $10-20 \mathrm{~cm}$ layers of each pot for the determination of physical and chemical properties. Soil Organic Carbon (OC), Total Nitrogen (TN), Total Phosphorus (P), pH, Electrical Conductivity (EC), Water Stable Aggregate (WSA), Mean Weight Diameter (MWD), Bulk Density (BD), C:N ratio and Total Porosity (Pt) were determined for the soil samples collected at the two layers.

\section{Plant growth parameters}

Plant growth parameters of plant height $(\mathrm{PH})$, number of leaves (NOL) and stem girth (SG) were monitored on weekly basis, starting from the fifth week after transplanting ( 5 WAT). $\mathrm{pH}$ was determined from the soil surface to the tip of last leaf using a steel tape; NOL was determined by visual counting of green leaves while SG was determined using a verniercaliper.

\section{Statistical Analysis}

Descriptive statistic and analysis of variance (ANOVA) were carried out on the soil properties and means were separated using
Tukey test at 5\% level of probability. Means between the two soil layers were compared using student's t-test. Pearson correlation test was also performed on soil properties. All statistical analyses were done using SPSS (IBM version 20.0) and SAS (version 8).

\section{Results and Discussion}

\section{Preliminary soil analysis}

The results of the preliminary investigation of the perceived degraded soil are shown in Table 1. The soil is slightly acidic $(\mathrm{pH}=$ 6.43) and the textural classification indicated that the soil is sandy loam textured. The soil is characterized by high bulk density which is reflected in the relatively low total pore space, with $\mathrm{Pt}$ about $0.31 \mathrm{~cm}^{3} / \mathrm{cm}^{3}$. The electrical conductivity (EC) was low for the soil to be considered saline. The organic carbon (OC) was 0.63 and $0.53 \%$ for the 0 $10 \mathrm{~cm}$ and $10-20 \mathrm{~cm}$ layers, respectively while total nitrogen (TN) was not more than $0.48 \mathrm{~g} / \mathrm{kg}$ (Table 1). Although the soil OC falls within $0.29-2.32 \%$ established for soils of southwest Nigeria (Adepetu and Corey, 1976), however a comparison with critical levels of $1.74 \% \mathrm{OC} ; 1.5 \mathrm{~g} / \mathrm{kg} \mathrm{TN}$ and 10.0 $\mathrm{mg} / \mathrm{kg} \mathrm{P}$ set for crop production in this region (Akinrinade and Obigbesan, 2000) showed that the these major soil nutrients are below critical. In terms of physical quality, the BD falls within the range (1.75$1.85 \mathrm{~g} / \mathrm{cm}^{3}$ ) considered restrictive to root growth and crop development (Reinert et al., 2008); impedance to water dynamics and gaseous exchange (Reichert et al., 2009) and which is reflected in low Pt observed. Therefore, for sustainable crop production and protection of the environment, amelioration is needed and organic manure, such as cow dung, could be of great help. The levels of mineral nutrients of the cow dung used for the study (Table 1) were 
within the range reported in literature (e.g. Adediran et al., 1999; Ewulo et al., 2007). Ewulo et al. (2007) stated that the faecal composition of cow dung cannot be the same as a result of age, type of feed and feeding system.

\section{Soil physical properties of the amended soil at harvest}

The addition of cow dung significantly $(\mathrm{p}<0.05)$ influenced the average soil bulk density (Table 2). The average values BD at depth 0-10 $\mathrm{cm}$ ranged between 1.65-1.78 $\mathrm{g} / \mathrm{cm}^{3}$, with the control (without cow dung) having the significantly highest BD value while cow dung application at 15 ton/ha (T2) had the lowest BD. Similar trend was observed at the depth $10-20 \mathrm{~cm}$ where the application of cow dung also showed significant difference $(p<0.05)$ compared with control although $\mathrm{T} 1$ had the lowest BD. A comparison of the two depths showed 10$20 \mathrm{~cm}$ layer had higher BD but this was not significantly difference from that of the $0-10$ $\mathrm{cm}$ surface layer (Table 2). In addition, the average $\mathrm{BD}$ of the $0-10 \mathrm{~cm}$ surface layer was lower than the pre-amended value while that of $10-20 \mathrm{~cm}$ was still at par.

The application of cow dung significantly $(\mathrm{p}<0.05)$ affected the soil total porosity $(\mathrm{Pt})$ at both depths (Table 2). For the $0-10 \mathrm{~cm}$ surface layer, the average values of $\mathrm{Pt}$ ranged between 0.33 and $0.39 \mathrm{~cm}^{3} / \mathrm{cm}^{3}$, with the control having the lowest value. A comparison between the three levels of cow dung showed that the application rate of 10 ton/ha (T1) gave the highest Pt. For the 10$20 \mathrm{~cm}$ layer, the average values of Pt ranged between 0.31 and $0.38 \mathrm{~cm}^{3} / \mathrm{cm}^{3}$, with the lowest and highest values from control and T1 treatment, respectively. A comparison between the two layers showed that the average $\mathrm{Pt}$ was at par $\left(0.35 \mathrm{~cm}^{3} / \mathrm{cm}^{3}\right)$. At harvest of eggplant, the $\mathrm{Pt}$ of the soil increased compared with the pre-amended value. The mean water stable aggregate (WSA) at the depth $0-10 \mathrm{~cm}$ ranged from 0.64 to 0.69 , with the lowest value from control which did not significantly $(\mathrm{p}<0.05)$ differ from other treatments (Table 2). For the $10-20 \mathrm{~cm}$ sub surface layer, average WSA was lower and ranged between 0.53 and 0.57 , with control having the lowest value. Treatments T2 (15 ton/ha) and T3 (20 ton/ha) had higher WSA than treatment T1 (10 ton/ha). The statistical comparison between treatments means showed that WSA did not significantly differ, however combining the treatments, the surface layer had significantly higher WSA compared with that of subsurface layer. Similarly, there was improvement in the WSA compared to pre-amended soil condition.

We went further to analyse the mean weight diameter (MWD) and similar trend was obtained as WSA (Table 2).

The improved soil structure characterized by decrease in $\mathrm{BD}$ and increase in $\mathrm{Pt}$ is attributed to improved aggregation and increased pore space caused by increased organic matter level of the soil due to cow dung. The non-significant difference in WSA may be attributed to the short duration of the experiment which could not allow enough time for the amendment (cow dung) to homogenize with the soil to form stable aggregates. Furthermore, the sandy nature of the soil could not favour inter-particle bonding to enable the amendment (cow dung) bind the soil particles to form stable aggregates (Khalid, 2010).

\section{Soil chemical properties of the amended soil at harvest}

The average values of $\mathrm{pH}$, electrical conductivity (EC), phosphorus (P), organic carbon (OC), total nitrogen (TN) and carbon-nitrogen ratio $(\mathrm{C}: \mathrm{N})$ of the two soil layers under different levels of cow dung 
amendment and control are presented in Table 3. At both depths, there was significant difference $(\mathrm{p}<0.05)$ in the $\mathrm{pH}$ between the control and treatments. For the surface layer, the control soil was more acidic $(\mathrm{pH}=6.05)$ compared with other treatments. In the subsurface layer, it was treatment $\mathrm{T} 1$ (10 ton/ha) that had the significant lowest value of $\mathrm{pH}$. Irrespective of treatments, the $0-10 \mathrm{~cm}$ surface layer had significantly higher $\mathrm{pH}$ than that of the 10$20 \mathrm{~cm}$ subsurface layer (Table 3 ). Compared with pre-amended soil $\mathrm{pH}$ values, the surface layer had the $\mathrm{pH}$ increased while the subsurface layer had its $\mathrm{pH}$ reduced. Our results agree with that of Ewulo et al., (2007) who found increased soil $\mathrm{pH}$ due to soil amendment by cow dung, the increase was attributed to addition of cations to the soil. Organic manure has also been reported to increase soil $\mathrm{pH}$ (Ullah et al., 2008), which helped to check the liming potential in an acidic soil.

There were significant differences $(\mathrm{p}<0.05)$ in the average values of EC between the control and treatments in both soil layers (Table 3). The EC significantly increased from $6 \mu \mathrm{s} / \mathrm{cm}$ in treatment $\mathrm{T} 1$ (10 ton/ha) to $12.67 \mu \mathrm{s} / \mathrm{cm}$ in treatment T3 (20 ton/ha) in the $0-10 \mathrm{~cm}$ layer. The opposite trend was observed in the 10-20 cm layer as the EC significantly decreased from about $14 \mu \mathrm{s} / \mathrm{cm}$ in treatment T1 (10 ton/ha) to about 29 $\mu$ s/cmin treatment T3 (20 ton/ha). Comparing the soil layers, the $10-20 \mathrm{~cm}$ layer had EC almost twice as much as that of the surface layer and these values were higher than the pre-soil amendment condition. Angelova et al. (2013) also reported that the addition of compost and vermicompost to the soils led to slightly increase in EC values compared with control soil. In addition, the increase in EC with increased doses of cow dung observed in the surface layer may be due to high salt concentration of the cow dung while the reduction in the subsurface layer is attributed to complex processes at play. Atiyeh et al. (2001) also observed increased EC with increasing application rates of pig manure.

The average values of total phosphorus (P) significantly $(p<0.05)$ differed in both soil layers due to the addition of cow dung (Table 3). In both layers, there was increase in soil $\mathrm{P}$ with increasing rate of cow dung, with soil receiving 20 ton/ha (T3) giving $P$ more than double that of soil that received 10 ton/ha (T1) and the control having the significantly lowest values. The values $\mathrm{P}$ from the control were comparable with those of pre-amended soil while those of the treated soils were higher than the initial values. Increase in soil $\mathrm{P}$ due to organic amendment has been reported by several researchers (e.g. Bayu et al., 2006; Ewulo et al., 2007; Padmavathiamma et al., 2008; Angelova et al., 2013). The greater than $200 \%$ increase in $\mathrm{P}$ when the application rate was double (from 10 to 20 ton/ha) and more than triple compared with control concurs with the findings of Devliegher and Verstraete (1997) who found a significant increase in the $\mathrm{P}$ contents after the vermicompost amendment, reaching double the initial value for some treatments, or even triple in others, which was attributed to increase in the enzymatic activity of phosphatases from earthworms.

The soil organic carbon (OC) and total nitrogen (TN) differed significantly in both soil layers as a result of soil amendment. In the $0-10 \mathrm{~cm}$ surface layer, the average values of $\mathrm{OC}$ and $\mathrm{TN}$ were higher from treated soils compared with the control while the different rates of cow dung did not differ from one another, although treatment T2 appeared having the highest (Table 3). In the subsurface layer, it was treatment T2 (15 
ton/ha) that had the highest values of OC and $\mathrm{TN}$ while treatment $\mathrm{T} 1$ had the lowest values. Nevertheless, the $0-10 \mathrm{~cm}$ surface layer had the significantly higher values of these parameters than the $10-20 \mathrm{~cm}$ subsurface layer. Compared with preamended soil condition, there was increase in both OC and TN at harvest. Several studies have also reported increase in soil $\mathrm{TN}$ and $\mathrm{OC}$ due to addition of farm yard manure (Bayu et al., 2006); cow dung (Ewulo et al., 2007) and compost (Angelova et al., 2013). The increased soil $\mathrm{TN}$ with increasing rate of cow dung showed that remarkable amount of $\mathrm{N}$ would be available for plant because of increased organic matter and favourable $\mathrm{pH}$ (Zupanc and Zupanc, 2010).

There was no significant difference in the carbon-to-nitrogen ratio $(\mathrm{C}: \mathrm{N})$ due to soil amendment in the two layers, however there was reduction in the $\mathrm{C}: \mathrm{N}$ ratio from about 14 from pre-amended soil to about 9 from amended soil (Table 3).In this study, the average values of $\mathrm{C}: \mathrm{N}$ of soil was low (around 9.6), below 20:1 considered minimum for $\mathrm{N}$ to be easily mineralised in all treatments, thus we can say there was good turnover of cow dung decomposition which is reflected in the increased TN. Our results agree with that of Angelova et al. (2013).

\section{Correlation between soil properties}

The result of the correlation analysis of the physico-chemical properties of the amended soils after the harvest of the vegetable was presented in Table 4. The OC and TN correlated significantly with $\mathrm{pH}, \mathrm{EC}$, WSA and MWD, while the correlation was positive with $\mathrm{pH}$, WSA and MWD, it was negative with EC. In addition, the MWD had significant positive correlation with the $\mathrm{pH}$. As expected, the BD had significant negative correlation with both WSA and MWD. P did not show correlation with any of the soil parameters, OC had perfect and positive correlation with $\mathrm{TN}$ while $\mathrm{BD}$ was almost perfectly correlated, though negative, with Pt. The varying degrees of significant correlations indicated that $\mathrm{OC}, \mathrm{TN}, \mathrm{pH}, \mathrm{EC}$, WSA, MWD and BD could be used to monitor the quality of soil when subjected to organic manure. It is however necessary to carry out further analysis, such as factor analysis, to determine which parameters that actually affect the soil and to focus on in other to avoid redundancy.

\section{Effect of cow dung manure on some growth parameters}

Figure 1a shows the effect of three rates of cow dung manure on the number of leaves (NOL) from 5 to 10 weeks after transplanting. Except at $8 \mathrm{WAT}$, application of cow dung significantly $(\mathrm{p}<0.05)$ influenced the NOL. NOL increased with increasing rate of cow dung only at 5 and 6 WAT and over time (10 WAT), T1 (10 ton/ha) produced the most number of leaves.

The average plant height $(\mathrm{PH})$ of eggplant under the different rates of cow dung manure is shown in Figure 1b. The application of cow dung had significant effect $(p<0.05)$ on $\mathrm{PH}$ throughout the monitoring period. There was also an increase in $\mathrm{PH}$ with increasing rate of cow dung applied throughout the growing cycle, with T3 (20 ton/ha) having the significantly highest plant, giving the order: T3>T2>T1. 
Table.1 Preliminary investigation of selected soil physico-chemical properties

Chemical properties

$$
\text { Soil layer, } \mathrm{cm} \quad \text { Cow dung }
$$

\begin{tabular}{lccc}
\hline & $0-10$ & $10-20$ & - \\
\cline { 2 - 4 } $\mathrm{pH}_{\mathrm{H} 2 \mathrm{O}}$ & 6.43 & 6.83 & 7.3 \\
$\mathrm{EC}(\mu \mathrm{s} / \mathrm{cm})$ & 7.67 & 5.33 & - \\
$\mathrm{P}(\mathrm{mg} / \mathrm{kg})$ & 7.36 & 4.48 & 7.8 \\
$\mathrm{OC}(\%)$ & 0.67 & 0.53 & 8.1 \\
$\mathrm{TN}(\mathrm{g} / \mathrm{kg})$ & 0.48 & 0.37 & 3.0 \\
$\mathrm{~K}(\%)$ & - & - & 1.3 \\
$\mathrm{Ca}(\%)$ & - & - & 0.9 \\
$\mathrm{Mg}(\%)$ & - & - & 0.3 \\
\hline
\end{tabular}

Physical properties

$\begin{array}{lccc}\mathrm{BD}\left(\mathrm{g} / \mathrm{cm}^{3}\right) & 1.78 & 1.79 & - \\ \mathrm{Pt}\left(\mathrm{cm}^{3} / \mathrm{cm}^{3}\right) & 0.312 & 0.305 & - \\ \text { WSA } & 0.654 & 0.532 & -\end{array}$

Particle size distribution, \%

\begin{tabular}{lccc}
\hline Sand & 76.60 & 74.60 & - \\
Silt & 12.92 & 12.86 & - \\
Clay & 10.48 & 12.54 & - \\
Texture & SL & SL & -
\end{tabular}

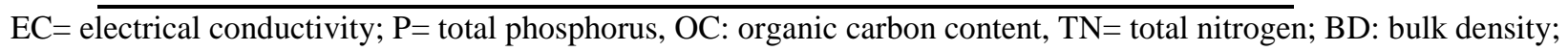
Pt: total porosity; WSA: water stable aggregate; SL: sandy loam 
Table.2 Some physical properties of the cow dung-amended soil after harvest of eggplant.

\begin{tabular}{|c|c|c|c|c|}
\hline \multirow[b]{2}{*}{ Treatments } & $\mathrm{BD}$ & $\mathrm{Pt}$ & WSA & MWD \\
\hline & \multicolumn{4}{|c|}{$0-10 \mathrm{~cm}$} \\
\hline $\mathrm{T} 1$ & $1.68 \pm 0.08 b$ & $0.39 \pm 0.01 \mathrm{a}$ & $0.66 \pm 0.02 a$ & $0.96 \pm 0.03 b$ \\
\hline $\mathrm{T} 2$ & $1.65 \pm 0.10 b$ & $0.36 \pm 0.03 b$ & $0.69 \pm 0.00 \mathrm{a}$ & $1.05 \pm 0.01 \mathrm{a}$ \\
\hline $\mathrm{T} 3$ & $1.70 \pm 0.06 b$ & $0.37 \pm 0.04 b$ & $0.67 \pm 0.02 \mathrm{a}$ & $1.03 \pm 0.04 \mathrm{a}$ \\
\hline Control & $1.78 \pm 0.04 \mathrm{a}$ & $0.33 \pm 0.01 \mathrm{c}$ & $0.64 \pm 0.04 a$ & $0.94 \pm 0.02 b$ \\
\hline Mean & $1.70 \mathrm{~A}$ & $0.35 \mathrm{~A}$ & $0.66 \mathrm{~A}$ & $1.00 \mathrm{~A}$ \\
\hline \multirow[t]{2}{*}{$\mathrm{LSD}_{\mathrm{T}}(\mathrm{p}<0.05)$} & 0.16 & 0.06 & 0.06 & 0.06 \\
\hline & \multicolumn{4}{|c|}{$10-20 \mathrm{~cm}$} \\
\hline $\mathrm{T} 1$ & $1.73 \pm 0.12 b$ & $0.38 \pm 0.03 a$ & $0.54 \pm 0.02 a$ & $0.82 \pm 0.04 \mathrm{ab}$ \\
\hline $\mathrm{T} 2$ & $1.78 \pm 0.15 b$ & $0.38 \pm 0.01 \mathrm{a}$ & $0.57 \pm 0.03 a$ & $0.88 \pm 0.04 a$ \\
\hline $\mathrm{T} 3$ & $1.73 \pm 0.07 \mathrm{~b}$ & $0.33 \pm 0.00 \mathrm{~b}$ & $0.57 \pm 0.03 \mathrm{a}$ & $0.87 \pm 0.05 a$ \\
\hline Control & $1.83 \pm 0.02 \mathrm{a}$ & $0.31 \pm 0.00 b$ & $0.53 \pm 0.01 \mathrm{a}$ & $0.76 \pm 0.02 b$ \\
\hline Mean & $1.77 \mathrm{~A}$ & $0.35 \mathrm{~A}$ & $0.55 \mathrm{~B}$ & $0.83 \mathrm{~B}$ \\
\hline $\mathrm{LSD}_{\mathrm{T}}(\mathrm{p}<0.05)$ & 0.21 & 0.04 & 0.04 & 0.07 \\
\hline
\end{tabular}

$\mathrm{T}_{1}=$ treatment with 10 ton/ha of cow dung; $\mathrm{T}_{2}=$ treatment with 15 ton/ha of cow dung; $\mathrm{T}_{3}=$ treatment with 20 ton/ha cow dung; BD: bulk density; Pt: total porosity; WSA: water-stable aggregate; MWD: mean weight diameter;

$\mathrm{LSD}_{\mathrm{T}}$ : least significant difference between treatments at $5 \%$ level of probability by Tukey test.

Means followed by the same lower case letters did not differ significantly between treatments while means followed by the same upper case letters did not differ significantly between soil depths by t-test. 
Table.3 Some chemical properties of the cow dung-amended soil after harvest of eggplant.

\begin{tabular}{lcccccc}
\hline & $\mathrm{pH} \mathrm{H}_{20}$ & $\mathrm{EC}(\mu S / \mathrm{cm})$ & $\mathrm{P}(\mathrm{mg} / \mathrm{g})$ & $\mathrm{OC}(\%)$ & $\mathrm{TN}(\mathrm{g} / \mathrm{kg})$ & $\mathrm{C}: \mathrm{N}$ \\
\cline { 2 - 7 } Trmts & \multicolumn{5}{c}{$0-10 \mathrm{~cm}$} \\
\hline $\mathrm{T} 1$ & $6.78 \pm 0.12 \mathrm{a}$ & $6.00 \pm 1.00 \mathrm{~b}$ & $9.24 \pm 1.98 \mathrm{~b}$ & $0.69 \pm 0.08 \mathrm{a}$ & $0.72 \pm 0.01 \mathrm{a}$ & $9.63 \pm 0.06 \mathrm{a}$ \\
$\mathrm{T} 2$ & $6.74 \pm 0.25 \mathrm{a}$ & $7.67 \pm 0.58 \mathrm{~b}$ & $10.40 \pm 0.69 \mathrm{~b}$ & $0.71 \pm 0.12 \mathrm{a}$ & $0.74 \pm 0.01 \mathrm{a}$ & $9.64 \pm 0.05 \mathrm{a}$ \\
$\mathrm{T} 3$ & $6.75 \pm 0.10 \mathrm{a}$ & $12.67 \pm 7.51 \mathrm{a}$ & $24.47 \pm 5.85 \mathrm{a}$ & $0.70 \pm 0.13 \mathrm{a}$ & $0.73 \pm 0.01 \mathrm{a}$ & $9.63 \pm 0.05 \mathrm{a}$ \\
Control & $6.05 \pm 0.22 \mathrm{~b}$ & $7.67 \pm 7.37 \mathrm{~b}$ & $7.36 \pm 8.29 \mathrm{~b}$ & $0.61 \pm 0.07 \mathrm{~b}$ & $0.64 \pm 0.01 \mathrm{~b}$ & $9.62 \pm 0.02 \mathrm{a}$ \\
Mean & $6.58 \mathrm{~A}$ & $8.50 \mathrm{~B}$ & $11.87 \mathrm{~A}$ & $0.68 \mathrm{~A}$ & $0.71 \mathrm{~A}$ & $9.63 \mathrm{~A}$ \\
LSD & 0.40 & 9.28 & 10.95 & 0.21 & 0.21 & 0.08 \\
\cline { 2 - 7 } T1 & & & $10-20 \mathrm{~cm}$ & & \\
\cline { 2 - 7 } T2 & $6.25 \pm 0.26 \mathrm{c}$ & $29.33 \pm 17.04 \mathrm{a}$ & $7.36 \pm 1.52 \mathrm{ab}$ & $0.40 \pm 0.19 \mathrm{c}$ & $0.41 \pm 0.02 \mathrm{c}$ & $9.67 \pm 0.04 \mathrm{a}$ \\
T3 & $6.57 \pm 0.11 \mathrm{ab}$ & $15.33 \pm 11.37 \mathrm{~b}$ & $9.68 \pm 3.25 \mathrm{ab}$ & $0.61 \pm 0.19 \mathrm{a}$ & $0.63 \pm 0.02 \mathrm{a}$ & $9.63 \pm 0.02 \mathrm{ab}$ \\
Control & $6.32 \pm 0.23 \mathrm{bc}$ & $5.33 \pm 1.15 \mathrm{c}$ & $4.48 \pm 6.49 \mathrm{~b}$ & $0.48 \pm 0.06 \mathrm{~b}$ & $0.50 \pm 0.01 \mathrm{~b}$ & $9.58 \pm 0.02 \mathrm{~b}$ \\
Mean & $6.40 \mathrm{~B}$ & $16.08 \mathrm{~A}$ & $9.63 \mathrm{~A}$ & $0.49 \mathrm{~B}$ & $0.51 \mathrm{~B}$ & $9.62 \mathrm{~A}$ \\
LSD $_{\mathrm{T}}$ & 0.32 & 25.37 & 10.77 & 0.30 & 0.31 & 0.07 \\
\hline
\end{tabular}

$\mathrm{T}_{1}=$ treatment with 10 ton/ha of cow dung; $\mathrm{T}_{2}=$ treatment with 15 ton/ha of cow dung; $\mathrm{T}_{3}=$ treatment with 20 ton/ha cow dung; Trmts: treatments; $\mathrm{EC}=$ electrical conductivity; $\mathrm{P}=$ total phosphorus, $\mathrm{OC}$ : organic carbon content, $\mathrm{TN}=$ total nitrogen and $\mathrm{C}: \mathrm{N}=$ carbon-nitrogen ratio.

$\mathrm{LSD}_{\mathrm{T}}$ : Least significant difference between treatments at $5 \%$ level of probability by Tukey test.

Means followed by the same lower case letters did not differ significantly between treatments while means followed by the same upper case letters did not differ significantly between soil depths by t-test. 
Int.J.Curr.Microbiol.App.Sci (2016) 5(8): $901-915$

Table.4 Correlation between soil properties

\begin{tabular}{|c|c|c|c|c|c|c|c|c|c|c|}
\hline & $\mathrm{pH}$ & EC & $P$ & $\mathrm{OC}$ & $\mathrm{TN}$ & C:N & WSA & MWD & $\mathrm{BD}$ & $\mathrm{Pt}$ \\
\hline $\mathrm{pH}$ & 1 & -0.353 & 0.400 & $0.412^{*}$ & $0.415^{*}$ & -0.089 & 0.395 & $0.474^{*}$ & -0.271 & -0.009 \\
\hline $\mathrm{EC}$ & & 1 & 0.171 & $-0.417^{*}$ & $-0.422^{*}$ & 0.272 & -0.180 & -0.101 & -0.099 & 0.349 \\
\hline $\mathrm{P}$ & & & 1 & 0.278 & 0.278 & 0.045 & 0.211 & 0.320 & -0.078 & 0.333 \\
\hline OC & & & & 1 & $1.000^{* *}$ & 0.200 & $0.524^{* *}$ & $0.542^{* *}$ & -0.252 & 0.238 \\
\hline $\mathrm{TN}$ & & & & & 1 & 0.186 & $0.522^{* *}$ & $0.540^{* *}$ & -0.251 & 0.234 \\
\hline $\mathrm{C}: \mathrm{N}$ & & & & & & 1 & 0.209 & 0.295 & -0.110 & 0.300 \\
\hline WSA & & & & & & & 1 & $0.976^{* *}$ & $-0.500^{*}$ & -0.100 \\
\hline MWD & & & & & & & & 1 & $-0.515^{*}$ & -0.026 \\
\hline $\mathrm{BD}$ & & & & & & & & & 1 & $-0.998^{* *}$ \\
\hline $\mathrm{Pt}$ & & & & & & & & & & 1 \\
\hline
\end{tabular}

*Correlation is significant at the 0.05 level (2-tailed).

**Correlation is significant at the 0.01 level (2-tailed).

Table.5 Correlation between plant growth parameters and soil properties

\begin{tabular}{lccc}
\hline & NOL & SG & PH \\
\hline $\mathrm{pH}$ & $0.607^{*}$ & 0.367 & $0.624^{*}$ \\
$\mathrm{EC}$ & -0.196 & 0.137 & 0.185 \\
$\mathrm{P}$ & 0.050 & 0.227 & 0.487 \\
$\mathrm{TC}$ & 0.231 & $0.657^{*}$ & -0.017 \\
$\mathrm{TN}$ & 0.233 & $0.671^{*}$ & -0.023 \\
$\mathrm{WSA}$ & -0.303 & -0.015 & 0.562 \\
$\mathrm{MWD}$ & -0.187 & -0.006 & $0.686^{*}$ \\
$\mathrm{BD}$ & -0.238 & -0.371 & -0.243 \\
Pt & $0.647^{*}$ & 0.425 & -0.015 \\
\hline
\end{tabular}

*Correlation is significant at the 0.05 level (2-tailed).

**Correlation is significant at the 0.01 level (2-tailed). 
Fig.1 Effect of different rates of cow dung manure on a) number of leaves (NOL); b) plant height $(\mathrm{PH})$ and c) stem girth (SG) during the crop cycle of the eggplant.
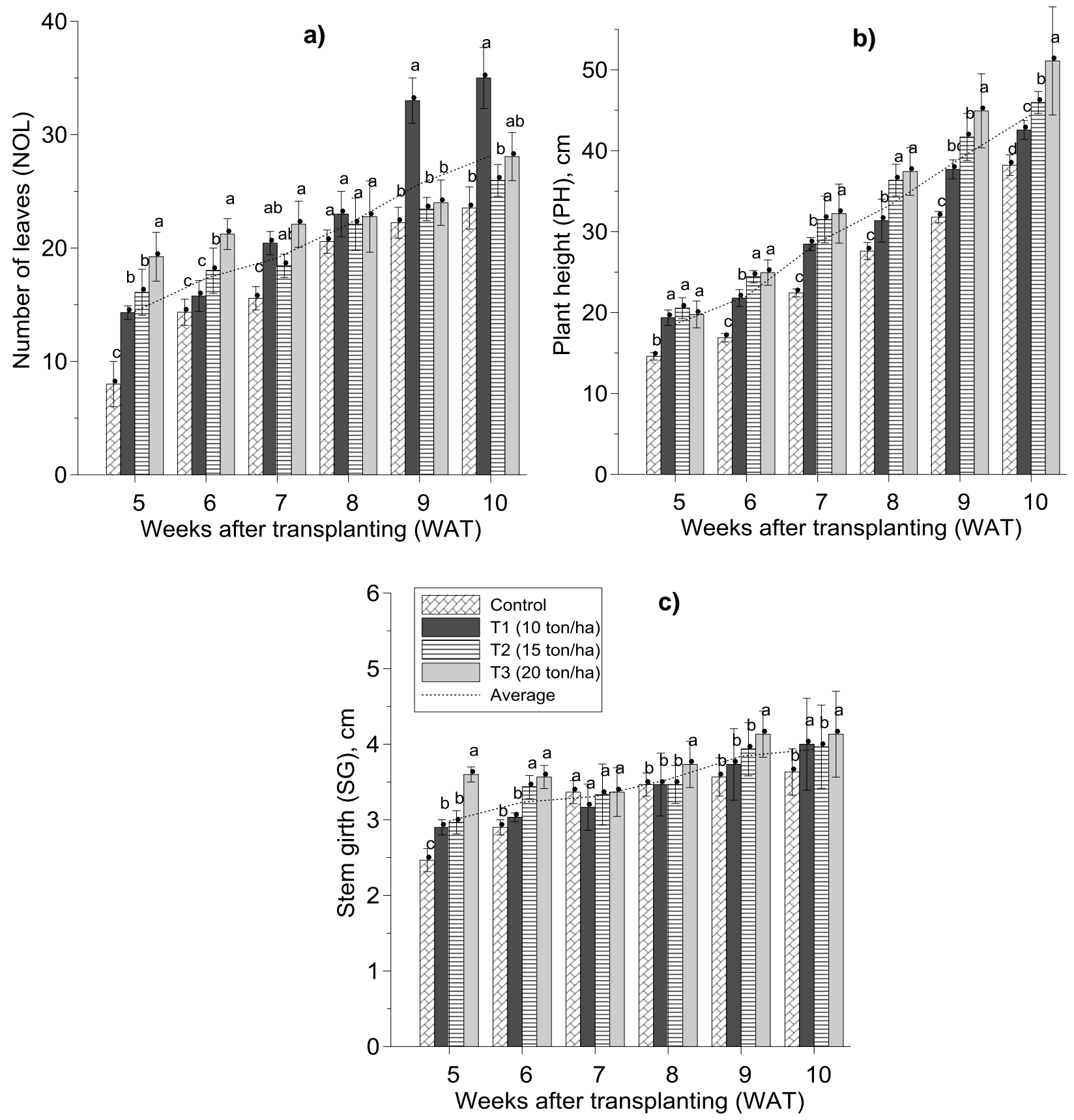

Means with different alphabets differed significantly at $5 \%$ level of probability by Tukey test. Vertical bars represent the standard error.

The effect of cow dung application on eggplant stem girth (SG) is presented in Figure 1c. Except at $7 \mathrm{WAT}$, the SG was also significantly $(\mathrm{p}<0.05)$ influenced due to the application cow dung manure, with T3 (20 ton/ha) having the highest SG. Over time (8-10 WAT), the average values of SG increased with increase in the rate of 
application of cow dung manure. A comparison between the control and amended soils showed that the growth parameters of NOL, PH and SG were significantly lowest from the control soil (Figures 1a-c).

The correlation between plant growth parameters and soil properties evaluated is shown in Table 5. The NOL and PH showed significant positive correlation with $\mathrm{pH}$ while the SG showed significant positive correlation with both $\mathrm{OC}$ and TN. The $\mathrm{PH}$ also showed moderate correlation with $\mathrm{P}$, though not significant. Both WSA and MWD correlated positively with $\mathrm{PH}$, with that of WSA not significant. All the plant growth parameters showed negative correlation with BD. On the other hand, the correlation between $\mathrm{Pt}$ and the growth parameters was positive except that of NOL was significant. Only the EC did not show appreciable correlation with the growth parameters.

The addition of different doses of cow dung manure had significant effect on vegetative growth of eggplant expressed by higher number of leaves, plant height and stem girth compared to the control. The turnover resulting from the decomposition of organic manure improves the nutrient cycling and availability to the plants especially, TN and $\mathrm{P}$ which improved root development and subsequently vegetative growth (Suge et al., 2011).The better performance from treatment T3 (20 ton/ha) is attributed to improved soil structural formation (decreased BD and higher Pt) by the decomposing manure, the roots were able to explore more soil volume, ensuring strong stems and taller plants. In addition, the increased soil $\mathrm{pH}$ by organic manure allowed the release of most nutrients. Ewulo et al. (2007) also reported improved plant growth and yield of pepper under different doses of cow dung. Suge et al. (2013) found higher growth parameters and yield of eggplant under organic manure compared to inorganic fertilizer.

In conclusion, the use of cow dung for soil amendment increased the organic matter content and improved the physical properties of the degraded soil. Essential nutrients, $\mathrm{TN}$ and $\mathrm{P}$, were significantly increased and made available due to increased $\mathrm{pH}$. The application of cow dung had positive impact on the growth of eggplant (Solanum melongena), with the application rate of 20 tons/ha giving the best results. The results showed that cow dung has great potentials for amelioration of degraded soils however further studies are required to establish optimum rate for sustainable crop production. The increase in $P$ loading with increasing application rates also call for further investigation in terms of negative impact on the environment.

\section{References}

Abubakari, A.H., L. Atuah, B. Banful, and Bayor, H. 2015. Use of soil amendments for urban horticulture in the savannah and forest areas of Ghana. J. Soil Sci. Env. Manag. 6(3), 51-57.

Adediran, J. A., M. O. Akande, L. B. Taiwo, and Sobulo, R.A. 1999. Comparative effectiveness of organic based fertilizer with mineral fertilizer on crop yield. In: Proceedings of Soil Sciences Society of Nigeria Conference, Babalola, O. (Ed), pp. 9195.

Ahmad, W., Farmanullah, Z. Shah, M. Jamal, and Shah, K.A. 2014.Recovery of organic fertility in degraded soil through fertilization and crop rotation. J. Saudi Soc. Agric. Sci. 13, 92-99.

Amhakhian, S. O., C. I. Oyewole, and Isitekhale, H.H. 2010. Effects of 
different levels of Phosphoruson the growth and yield of maize (Zea mays L.) in Ofere (Basement complex) soils Kogi State, North Central ecological zone, Nigeria. Continental J. Agric. Sci.4, 20-28.

Akinrinade, E. A., and Obigbesan, G. O. 2000. Evaluation of the fertility status of selected soils for crop production in five ecological zones of Nigeria.In: Proceedings of the $26^{\text {th }}$ Annual Conference of Soil Science Society of Nigeria, Ibadan, pp. 279-288.

Alves, M. C., and Souza, Z. M. 2008.Recuperação de áreadegradada porconstrução de hidroelétrica com adubaçãoverde e corretivo.Rev. Bras. Ci. Solo.32,2505-2516.

Angelova, V. R., V. I. Akova, N. S. Artinova, and Ivanov, K.I. 2013.The effect of organic amendment on soil chemical characteristics. Bulg. J. Agric. Sci. 19, 958-971.

Atiyeh, R. M., C. A. Lee Edward, S. Sulbarand Metzger, T.2001. Pig manure vermicompost as a component of a horticultural bedding plant medium: Effects on physiochemical properties and plant growth. Bioresour. Technol.78,11-20.

Bayu, W., N. F. G. Rethman, P. S. Hammes, and Alemu, G. 2006. Application of farmyard manure improved the chemical and physical proeprties of the soil in a semo-arid area in Ethiopia. Biol. Agric. Hort. 24(3), 293-300.

Bonini, C., and Alves, M. C. 2010. Relation between soil organic matter and physical properties of a degraded Oxisol in recovery with green manure, lime and pasture.In: Proceedings of $19^{\text {th }}$ World Congress of Soil Science, Soil Solutions for a changing World, 1-6 August, 2010, Brisbane, Australia, pp. 198-201.
Devliegher, W., and Verstraete, W.1997. The effect of Lumbricusterrestris on soil in relation to plant growth: effects of nutrient-enrichment processes (NEP) and gut-associated processes (GAP). Soil BiolBiochem.29, 341346.

Ewulo, B.S. 2005. Effect of poultry dung and cattle manure on chemical properties of clay and sandy clay loam. J. Anim. Vet. Adv. 4, 839-841.

Ewulo, B. S., K. O. Hassan, and Ojeniyi, S.O. 2007.Comparative effect of cow dung manure on soil and leaf nutrients and yield of pepper.Int. J. Agric. Res. 2(12), 1043-1048.

Fening, J. O., T. Adjei-Gyapong, E. Yeboah, E.O. Ampontuah, G.Quansah, and Danso, S.K.A. 2008. Soil fertility status and potential organic inputs for improving small holder crop production in the interior savannah zone of Ghana. J. Sustain. Agric. 25(4), 69-92.

Ganiyu, M. O., T. N. Akinniran, and Adeyemo, S.A. 2013. Rainfall Pattern and Trend On Arable Crops Production In Oyo State, Nigeria (1990-2009).

Ikeh, A. O., E.I.Udoh, G. I. Uduak, P. I. Udounag, and Etokeren, U.E. 2012.Response of cucumber (Cucumis sativus L.) to different rates of goat and poultry manure on an ultisol. J. Agric. Soc. Res. 12(2), 132-139.

Khalid, A. Z. 2010.Effects of Poultry Manure and NPK Fertilizer on Growth and Yield of Garden Eggs (Solanummelongena) in a sandy soil in Ghana.A MSc Thesis submitted to the Faculty of Agricultural and Natural Resources Kwame Nkrumah University of Science and Technology, Kumasi, Ghana.

McGeehan, S.L. 2012. Impact of waste materials and organic amendments on 
soil properties and vegetative performance.Appl. Env. Soil Sci.doi: 10.1155/2012/907831.

Obeng-Ofori, D., E. Y. Danquar, and OfosuAnim, J. 2007. Vegetable and spice crop production in West Africa. The City Publishers Limited, Ghana, pp. 77-79.

Olaniyan, A. B., and Nwachukwu, K. 2003. Response of Solanum macrocarpon to different sources of nitrogen fertilizer. In: Proceedings of the 6th Biennial Conference of the African Crop Science Society, Hilton Hotel Nairobi, Kenya, October $12^{\text {th }}-17^{\text {th }} 2003$..

Olaniyi, J. O., W. B. Akanbi, T.A.Adejumo, and Akande, O.G. 2010. Growth, fruit yield and nutritional quality of tomato varieties. Afric. J. Food Sci. 4(6), 398402.

Oyewole, C. I., E. S. Akogu, and Attah, E.S. 2014. Response of Eggplant (Solanummelongena L.) to Nutrient Sources and Rates of Application: I. Yield Components and Fruit Yield. International Journal of Agriculture and Bioscience 3(4), 166-172.

Padmavathiamma, P.K., L.Y. Li, and Kumari, U.R.2008.An experimental study of vermi-biowaste composting for agricultural soil improvement. Biores. Tech.99 (6), 1672-1681.

Reichert, J.M., L.E.A.S.Suzuki, D.J.Reinert, R.Horn, and Hakansson, I. 2009. Reference bulk density and critical degree-of-compactness for no-till crop production in subtropical highly weathered soils.Soil Till. Res. 102, 242-254.

Reinert, D.J., J.A.Albuquerque, J.M. Reichert, C.Aita, and Andrada, M.M.C. 2008. Limitescríticos de densidade do solo para o crescimento de raízes de plantas de coberturaemArgissoloVermelho. Rev. Bras. Ci. Solo. 32, 1805-1816.

Stoorvogel, J.J., E.M.A.Smaling, and Janssen, B.H. 1993. Calculating soil nutrient balances in Africa at different scales: I. Supra-national scale. Fert. Res.35, 227-235.

Suge, J.K., M.E.Omunyin, and Omami, E.N. 2011.Effect of organic and inorganic sources of fertilizer on growth, yield and fruit quality of eggplant (Solanum melongena L). Arch. Appl. Sci. Res. 3(6), 470-479.

Tindall, H. D. 1992. Vegetables in the tropics: The Macmillan press Limited, London and Basingstoke. pp 363 367.

Ullah, M. S., M. S. Islam, and Haque, T. 2008. Effects of organic manure and chemical fertilizers on the yield of brinjal and soil properties.Journal Bangladesh Agricultural University. 271-276.

Zupanc, V., and Zupanc, J. M.2010.Changes in soil characteristics during landfill leachate irrigation of Populus deltoids. Waste Manag.30, 2130-2136.

\section{How to cite this article:}

Abegunrin, T.P., G.O. Awe and Ateniola, K.O. 2016. Soil Amendment for Vegetable Production: An Example with Cow Dung Manure and Eggplant (Solanum melongena). Int.J.Curr.Microbiol.App.Sci. 5(8): 901-915. doi: http://dx.doi.org/10.20546/ijcmas.2016.508.102 